\title{
Hadis Nabi, Salafisme dan Global Terrorism
}

\author{
M. Khoirul Huda ${ }^{1}$
}

\begin{abstract}
This article concludes that there is a strong genealogical relation between hadith, salafism and global terrorism. Salafism puts an emphasis on hadith as a worldview and on literal understanding of hadith. When this ideology meets with the political interest, this ideology produces global violent actions framed under the scheme of global terrorism. This view is forwarded by some scholars, such as Anne Speckhard, Khapta Akhmedova, Mumtaz Ahmad, and Yoginder Sikand.

In this study, the author uses intellectual historical approach analyzing the history of salafism ideas, their hadith worldview, and textual understanding of hadith.
\end{abstract}

\begin{abstract}
Abstrak
Artikel ini berkesimpulan bahwa ada hubungan genealogis yang kuat antara hadis, ideologi salafisme dan terorisme global. Salafisme menempatkan hadis sebagai worldview dan menekankan pemaknaan tekstual terhadap hadis Nabi saw. Ketika bertemu kepentingan politik, ideologi ini melahirkan aksi-aksi kekerasan global yang terbingkai dalam diskursus global terrorism. Pandangan ini dikemukakan sejumlah sarjana seperti Anne Speckhard dan Khapta Akhmedova, Mumtaz Ahmad, dan Yoginder Sikand.

Dalam melakukan kajian ini, penulis menggunakan pendekatan sejarah intelektual (intellectual history) dengan menganalisis sejarah ide salafisme, perumusan pandangan dunia berbasis hadis (hadith worldview) dan metode pemahaman tekstualis.
\end{abstract}

Keywords: Salafisme, Hadith Worldview dan Tekstualisme

1 Peneliti di Yayasan Pengkajian Hadis "El-Bukhari Institute." Banten, dan Asisten Peneliti pada Institute for International Peace Building (IIB), Jakarta. E-mail: chairool_hoeda@yahoo.co.id 


\section{Pendahuluan}

Sejak tahun 60-an telah terjadi pergeseran paradigma dalam aksi-aksi teror. Sebelum tahun 1968, istilah teror lebih banyak dikaitkan dengan aksi pembunuh bayaran (assasint), gerakan kaum anarkhis anti-negara (anarchis terrorist), dan aksi kekerasan oleh negara (state terrorism). Setelah itu, terorisme mulai berkembang dengan menggunakan agama sebagai basis ideologi. Inilah yang disebut oleh sebagian pihak dengan teror berbasis agama (religius terrorism). ${ }^{2}$

Teror berbasis agama ini lahir bersamaan dengan proyek kebangkitan agama. Pada dasarnya ada dua pola besar dalam fenomena kebangkitan ini. Pertama, kebangkitan semangat beragama yang menggunakan saluran-saluran kultural. Kebangkitan jenis ini cenderung apolitis, lebih mengedepankan edukasi dan pengkayaan pengalaman rohani. Dalam konteks Islam, hal ini dapat diamati pada menjamurnya fenomena sufi urban, jamaah tabligh, syariatisasi lembaga keuangan, gerakan filantropi dan sejenisnya.

Kedua, kebangkitan yang menggunakan saluran politik. Dalam beberapa kasus kebangkitan model ini melibatkan kekerasan dalam mengekspresikan semangat ke(ber)agamaannya. Partai Islam, gerakan yang mengkampanyekan negara Islam, anti-sekulerisme, dan yang paling akhir terorisme agama merupakan dampak dari kebangkitan agama pola kedua ini. Dengan demikian, pada dasarnya, terorisme agama merupakan sejenis aksi politik untuk memperoleh tujuan-tujuan politis ketimbang pemuasan hasrat rohani masyarakat.

Kebangkitan agama yang bertemu dengan kepentingan politik dan melahirkan kekerasan-kekerasan teroristik telah memakan jutaan nyawa manusia. Tentu saja masalah ini telah menjadi isu global yang menarik perhatian dunia.

World of Health Organization (WHO) melaporkan bahwa jumlah korban tewas akibat kekerasan per 2011 mencapai angka rata-rata 1,3 juta jiwa tiap tahunnya. ${ }^{3}$ Bahkan Centers Disease Control dan Prevention (CDC) menyebut angka 1,6 juta orang. Lebih dari $90 \%$ di antaranya berasal di negara-negara

${ }^{2}$ Gérard Chaliand dan Arnaud Blin, The History of Terrorism From Antiquity To Al Qaeda (California: University of California Press, 2007), 252; Amy Zalman, The History of Terrorism, dikutip dalam laman http://terrorism.about.com/od/whatisterroris1/p/Terrorism.htm. Pada 03.09.2014. jam. 14.46. Satu P. Limaye et.all, Religious Radicalism and Security in South Asia (Honolulu: Asia-Pasific Center for Security Studies, 2004), 1.

${ }^{3}$ Lihat Global Status Report on Violence Prevention. Diakses dari http://www.who.int/violence_injury__ prevention/violence/status_report/en. 28-082014.21.906. 
berpenghasilan rendah dan menengah. ${ }^{4}$ Dari sekitar satu setengah juta orang tersebut sebagian di antaranya meninggal dalam aksi kekerasan terorisme. Study of Terrorism and Responses to Terrorism (START) melaporkan bahwa pada 2012 saja, aksi terorisme telah memakan korban 15.500 jiwa. Mereka merupakan korban dalam 8500 serangan. ${ }^{5}$ Berdasarkan data ini, dapat dihitung secara kasar bahwa setiap bulan ada sekitar 700 jiwa melayang atau 23 orang dibantai tiap hari.

Kematian lima belas ribu orang dalam setahun dalam aksi teror sepertinya tidak menyadarkan para aktor terorisme. Faktanya, kekerasankekerasan atas nama agama tetap berjalan dan terus merekrut kader-kader baru. Generasi-generasi baru teroris pun siap mengisi daftar kematian mereka dengan penuh kebanggaan. Seakan tanpa memikirkan sedikit pun dampak aksi-aksi kekerasan mereka terhadap orang-orang seagamanya. Bagaimana pun, aksi kekerasan dalam konteks teror ini tidak menguntungkan umat Islam, karena negara yang berciri penduduknya berpenghasilan rendah-menengah adalah negara-negara mayoritas Muslim. Artinya, korban kekerasan global terorisme itu adalah umat Islam sendiri.

Para pemerhati terorisme agama hampir sepakat bahwa dalam konteks Islam, terorisme agama mendapatkan pembenaran dari, kalau tidak kita sebut "didorong" oleh pemikiran jihad kelompok salafi (salafist school). ${ }^{6}$ Anne Speckhard dan Khapta Akhmedova meneliti generasi baru Jihadis Checnya yang merupakan pengikut militan Wahhabi, sebuah kelompok yang selalu mengklaim sebagai penganut paham salafi. ${ }^{7}$ Mumtaz Ahmad mengamati bahwa Bangladesh menjadi tempat penyemaian kelompok radikal Islam melalui organisasi Ahl-eHadith. Kelompok ini merupakan anak ideologis gerakan salafi India. ${ }^{8}$ Yoginder Sikand melihat adanya perubahan orientasi perlawanan para militan Kashmir. Awalnya mereka melakukan perlawanan untuk mendapatkan kemerdekaan nasionalnya dari India (national liberation), namun pada perkembangan terakhir

\footnotetext{
${ }^{4} \mathrm{http}: / /$ www.cdc.gov/violenceprevention/globalviolence.

${ }^{5}$ Lihat laporan CNN dalam terrorist Attacks And Deaths Hit Record High, dikutip dari http://religionblogs.cnn.com 2013/10/28/ terrorist-attacks-and-deaths-hitrecord-high-report-shows.

${ }^{6}$ Lihat misalnya, Febe Armanios, The Islamic Traditions of Wahhabism and Salafiyya, CRS Report for Congress. Didownload dari fas.org/sgp/crs/misc/RS21695.pdf. Iffah Muzammil, "Global Salafisme Antara Gerakan dan Kekerasan," Teosofi: Jurnal Tasawuf dan Pemikiran Islam 3, 1 (1 Juni 2013).

${ }^{7}$ Anne Speckhard dan Khapta Akhmedova dalam "The New Chechen Jihad: Militant Wahhabism as a Radical Movement and a Source of Suicide Terrorism in PostWar Chechen Society," Democracy and Security, 2 (2006):103-155.

${ }^{8}$ Mumtaz Ahmad, Ahl-e-Hadith Movement in Bangladesh: History, Religion, Politics and Militancy.
} 
muncul upaya pembingkaian perjuangan mereka dalam konteks jihad. Bagi Sikand, perubahan ini sangat berhubungan dengan pandangan jihad kaum salafi. ${ }^{9}$

Dalam banyak laporan, Al Qaeda, dinilai banyak pihak sebagai aktor utama yang mengekspor ide-ide jihad salafi ke seluruh dunia. Burke dalam artikel berjudul "Al-Qaeda" menyatakan bahwa organisasi ini sekarang lebih dari sekadar organisasi biasa. Ia sudah menjadi ideologi yang dia sebut "AlQaedaisme". Prinsip utamanya adalah melawan peradaban Barat menggunakan jalan jihad dan memperjuangkan tegaknya ajaran Islam. ${ }^{10}$ Di beberapa bagian dunia, Al Qaedaisme telah mengilhami lahirnya gerakan jihad lokal seperti Taliban di Afganistan, ${ }^{11}$ Islamic State (IS), ${ }^{12}$ dan yang terakhir adalah gerakan jihad organisasi Boko Haram di Nigeria. ${ }^{13}$

Dari sini dapat digambarkan bahwa kaum salafi cukup dekat dengan tradisi kekerasan dan intoleransi. Radikalisme Islam yang bermetamorfosis menjadi gerakan teror dunia (global terrorism) dinilai banyak pihak berhubungan erat dengan pandangan kaum salafi. ${ }^{14}$ Kaum salafi merupakan kelompok Islam yang mencita-citakan lahirnya kehidupan yang sesuai dengan zaman Nabi saw. Ciri utamanya adalah kembali kepada sumber-sumber suci secara literal-tekstual. Adis Duderija mengategorikan mereka dalam bendera Neo-Traditionalist Salafist (NTS). Metode tekstualnya disebut hermeneutika

${ }^{9}$ Yoginder Sikand, Changing Course of Kashmiri Struggle: From National Liberation to Islamist Jihad? Sumber:http://www.jstor.org/stable/4410197. Diakses pada 27-08-2014, 02:32.

10 Jason Burke, “Al-Qaeda," sumber: http://www.jstor.org/stable/ 4147572. Diakses pada 28-08-2014 03:00. Encyclopædia Britannica, Al-Qaeda, http://www.britannica.com/EBchecked/topic/734613/al-Qaeda. Diakses pada 27-12-2014, jam 10.07.

${ }^{11}$ History of Taliban, http://www-pub.naz.edu/aamghar6/History\%20of \%20the\%20Taliban. htm. Diakses pada 27-12-2014. 10.03 WIB.

${ }_{12}$ Aaron Y. Zelin, The War between ISIS and al-Qaeda for Supremacy of the Global Jihadist Movement, diunduh dari http://www.washington-institute.org/policyanalysis/view/the-war-between-isis-and-al-qaeda-for-suprema-cy-of-the-global-jihadist. Pada 27-12-2014 jam 10.12.

13 Freedom C. Onuoha, Boko Haram: Nigeria's Extremist Islamic Sect, Al Jazeera Center for Studies. studies.aljazeera.net. diakses pada 27-12-2014 jam 10.18.

${ }_{14}$ Sebagian sarjana membedakan dua model salafisme, yaitu salafi yang berorientasi politik dan salafi non-politis. Salafi politik mempunyai dua pola. Yaitu mereka yang masih mengakui institusi negara bangsa serta berjuang dalam koridor konstitusi, dan salafi yang dalam perjuangannya menggunakan cara-cara non konstitusional. Yang terakhir ini sebagian menggunakan jalan kekerasan dalam memperjuangkan ide-idenya. 
Qurano-Sunnah. ${ }^{15}$ Dalam bahasa Ulumul Qur'an konvensional, metode pemahaman mereka tergolong tafsir bi-al-ma'th $\overline{u r}$, suatu model penafsiran yang didasarkan kepada riwayat-riwayat. Pola umum penafsiran model ini adalah penekanan yang berlebih kepada hadis. Bahkan bisa dikatakan bahwa penafsiran bi al-ma'tsur ini menundukkan al-Quran kepada hadis. Hadis kemudian menjadi lebih dominan dibanding al-Quran yang pada umumnya menggunakan redaksi yang bersifat general. Salafisme dengan demikian merupakan sebentuk dominasi nalar hadis dalam proses penafsiran. Perujukan kepada hadis menjadi keniscayaan tersendiri.

Di sini muncul pertanyaan mengenai apakah, dengan demikian, pemikiran salafisme merupakan dampak dari penggunaan hadis, atau sebaliknya, salafisme merupakan kecenderungan yang mencoba membingkai hadis dalam suatu narasi tertentu. Terlebih narasi kekerasan yang sering ditampilkan kaum salafi jihadi akhir-akhir ini.

Untuk menjawab pertanyaan ini, penulis akan menampilkan analisis historis terhadap genealogi gerakan salafi. Penulis mencoba meminjam teori sejarah intelektual (intellectual history) untuk menangkap perkembangan pemikiran salafisme. Penulis mencoba menggunakan model analisis wacana kritis dalam melihat diskursus salafisme ini.

\section{Salafisme; Akar dan Gerakan}

Kata salafisme saat ini telah menjadi terma global. Sebagai buktinya, Oxford Dictionaries memasukkannya sebagai entri kamus. Dalam kamus ini, salafi diartikan "a member of a strictly orthodox Sunni Muslim sect advocating a return to the early Islam of the Koran and Sunna"(kelompok Muslim Sunni ortodoks yang menganjurkan kembali kepada Islam awal yang berlandaskan Alquran dan Sunnah). ${ }^{16}$ Salafi diambil dari bahasa Arab, salaf (السلف). Kata ini berarti taqaddam wa sabaq (dahulu atau kuno). ${ }^{17}$ Menurut Said Ramadhan alButhi, kata salaf dalam pengertian awalnya merupakan kata ambigu dan nisbi. Salaf yang berarti "dahulu" mencakup semua waktu yang mendahuluhi waktu yang lain. Ia dapat merujuk kepada seluruh waktu. Namun dalam pengertian terminologisnya salaf berarti tiga abad pertama sejak umat Islam pertama kali

${ }^{15}$ Adis Duderija, "Toward a Methodology of Understanding the Nature and Scope of the Concept of Sunnah," Arab Law Quarterly 21 (2007): 1-12, sumber: www.brill.nl/alq. Iffah Muzammil, "Global Salafisme Antara Gerakan Dan Kekerasan," english/Salafi

${ }_{16}$ Dikutip dari http://www.oxforddictionaries.com /us/definition/american

${ }^{17}$ Ahmad bin Faris bin Zakaria al-Razi, Mu'jam Maqāyis al-Lughah (Beirut: Dar al-Fikr, 1979), jilid 3, 95. 
muncul pada abad ketujuh masehi. Konsep ini berasal dari sebuah hadis yang menyatakan bahwa abad terbaik adalah abad saat Nabi hidup, kemudian tiga zaman setelahnya. $^{18}$

Saat ini, salafisme merupakan gerakan sosial yang beragam bentuknya. Mereka membentuk organisasi-organisasi di setiap negara. Tak jarang satu dengan yang lainnya saling menyalahkan dan mengkafirkan. Adis Duderija dan Iffah Muzammil menyatakan bahwa salafisme merupakan gerakan global saat ini. ${ }^{19}$ Yasir Qadhi mencatat beberapa karakteristik umum yang selalu nampak dalam semua model gerakan salafisme, dan sepertinya para sarjana hampir sepakat dengan karakteristik ini.

Pertama, mereka menganggap diri mereka sebagai pengemban ajaran dan keyakinan salaf al-shalih yang paling benar. Mereka meyakini kredo teologis yang diriwayatkan dari generasi salaf. Ini yang disebut dengan akidah salaf. Kedua, mereka menolak kemungkinan penafsiran metaforis atau simbolik pada nama dan sifat Tuhan yang menjadi karakter paham Muktazilah dan Asy'ariyyah. Hal ini berhubungan dengan prinsip tauhid asma wa sifat. Penyucian nama dan sifat Tuhan. Ketiga, mereka menegaskan hak eksklusif Allah sebagai sesembahan (tauhid uluhiyyah). Mereka menolak segala yang bertentangan dengan prinsip ini seperti yang dikembangkan oleh kaum sufi dalam ritual tawasul, ziarah, dan lainnya. Keempat, mereka menentang segala macam inovasi (bid'ah) serta memusuhi penganutnya. Di antara kaum bid'ah yang dimusuhi adalah kelompok Syiah yang mengeritik cukup banyak sahabat. Kelima, mengamini pendapat hukum dan pandangan teologis Syaikhul Islam Ibnu Taimiyyah. Kaum salafi di dunia modern hampir menggantungkan semua pandangan teologisnya kepada tokoh ini. ${ }^{20}$

Salafisme modern merujuk kepada gerakan keagamaan yang dimotori oleh Muhammad Abduh dan Rasyid Ridha di Mesir pada abad dua puluh, dan Muhammad bin Abdul Wahhab pada abad delapan belas di Jazirah Arab. Kedua gerakan ini merupakan bentuk revivalisme Islam. Dari Muhammad bin Abdul Wahhab lahir sebutan lain yang disematkan oleh lawan-lawannya yaitu Wahabisme. Kedua gerakan ini sepakat untuk mengkampanyekan gerakan

${ }^{18}$ Said Ramadhan al-Buthi, al-Salafiyyah Marhalah Zamāniyyah Mubārakah Lā Madhab Islāmī (Damaskus: Dar al-Fikr, 1988), cet. ke-1, 9.

${ }^{19}$ Adis Duderija, "Islamic Groups and Their World-Views and Identities: NeoTraditional Salafis and Progressive Muslims," Arab Law Quarterly 21,4 (2007): 341-363, diakses dari http://www.jstor.org/stable/27650599 pada 28-08-2014 05:26

20 Yasir Qadhi, On Salafi Islam, didownload dari muslimmatters.org/2014/04/22/on-salafi-islam-dr-yasir-qadhi. Pada 27-12-2014 jam 11.37 . 
kembali kepada Al-Quran dan Sunnah (going back to the Quran and Sunnah). ${ }^{21}$ Bahkan Adis Duderija menyatakan bahwa turunan kedua model pemahaman keagamaan ini telah menjadi gerakan Muslim global kontemporer. Pengaruh salafi-Wahabi menjelma menjadi aliran yang disebut Neo Traditional Salafist. Sedangkan pengaruh liberasi pemikiran Muhammad Abduh bermetamorfosis menjadi Progressif Muslim. ${ }^{22}$

Wahabisme menyebar ke berbagai wilayah di dunia Islam melalui jaringan intelektual. Charles Allen misalnya menemukan bahwa Wahabisme yang bersumber dari Arab Saudi sudah diadopsi oleh sejumlah intelektual India yang pernah belajar ke Madinah pada abad delapan belas. Di India sebenarnya sudah ada gerakan kebangkitan Islam yang dimotori oleh kaum sufi seperti Syah Waliyyullah dari Delhi. Syah Waliyyullah dikenal sebagai penganut mazhab fiqh Hanafi dan mursyid Thariqah Naqsyabandi. Dia pernah belajar kepada Ibrahim al-Kurani. Ulama yang menjadi simpul jaringan ulama global abad delapan belas asal Kurdi. Syah Waliyyullah belajar hadis kepada Ibrahim alKurani dan membawanya ke India. Perjuangannya diwujudkan dalam bentuk pembangunan madrasah hadis di wilayah utara India. Usahanya diteruskan oleh anaknya Syah Abdul Aziz. Ketika belajar di Arab, Syah Waliyyullah satu perguruan dengan Syekh Muhammad bin Abdul Wahhab. Namun keduanya berbeda dalam menyikapi tradisi tasawuf dan fiqh. Beberapa tahun kemudian, seorang murid Syah Abdul Aziz bernama Syed Ahmad dari Rae Bareili pergi ke Arab Saudi untuk belajar agama, bertepatan dengan mapannya paham Muhammad bin Abdul Wahhab atas dukungan Amir Ibnu Saud, pendiri kerajaan Arab Saudi. Setelah kembali ke tanah air, Syed Ahmad Rae Bareili mengembangkan ajaran radikal Wahabi. Dia memelopori perang terhadap singkretisme Muslim India, dan memproklamirkan India sebagai dar al-kufr, setelah lepas dari kekuasaan kerajaan Mughal dan masuk dalam jajahan Inggris. Karenanya, kaum Muslim tidak boleh tunduk kepada pemerintahan kafir. ${ }^{23}$

Di Indonesia, paham salafi mulai masuk bersamaan dengan pulangnya jamaah haji pada era penjajahan Belanda. Para haji itu mencoba melakukan upaya permunian agama dan menentang adat-adat yang dinilai melenceng dari ajaran agama. Gerakan lokal ini disebut gerakan kaum Padri. Dalam upaya ini, mereka berhadapan dengan kaumd Adat yang pada dasarnya adalah orang-orang

21 Christopher M. Blanchard, The Islamic Traditions of Wahhabism and Salafiyya, CRS Report for Congress.

${ }^{22}$ Adis Duderija, "Islamic Groups and Their World-Views and Identities."

${ }^{23}$ Charles Allen, "The Hidden Roots of Wahhabism in British India," World Policy JournaL, 22 (2005): 87-93. Diakses dari www.-jstor.org/stable/402099677 pada 19-10-2014 jam 06.57. 
Muslim juga. Yang membedakan adalah kelompok terakhir berupaya melakukan islamisasi secara bertahap, sedangkan yang pertama cenderung ingin segera menuntaskan keutuhan penerapan syariat Islam. Hubungan kedua kelompok ini semakin memburuk dan berakhir dengan perang. Banyak pihak menyebut perang saudara ini adalah perang bercorak agama. ${ }^{24}$

\section{Salafisme dan Hadis}

Ulasan sebelumnya menunjukkan bahwa dalam melancarkan perang terhadap "yang lain" kaum salafi menggunakan hadis, baik dalam menjelaskan persoalan penafsiran Al-Quran maupun sosial politik dan pengetahuan. Hadis menjadi sentral argumen yang mengalahkan, bahkan Al-Quran sekalipun.

Menurut George Tharabisyi, perkembangan ini terjadi sejak abad kedua hijriah, ketika al-Syafi'i (204 H.) merumuskan posisi teoritik sunnah sebagai bagian dari rujukan otoritatif dalam masalah keagamaan dan kebudayaan. Sunnah yang tadinya diperdebatkan otoritasnya, pada era itu mulai diakui kedudukannya. Pada abad ketiga bahkan muncul profesional dalam bidang hadis yang melanjutkan proyek al-Syafi'i. Bahkan terjadi proses radikalisasi terhadap pemikiran al-Syafi'i. Sebut saja Ahmad bin Hanbal dan Dawud bin Ali alZhahiri. Imam-imam hadis pada abad ketiga hijriah merupakan eksponen pemikiran al-Syafi'i. Dominasi nalar hadis berujung kepada sejumlah kemandegan berfikir. Menurutnya, dominasi nalar hadis berakibat pada hilangnya peran sentral al-Qur'an dalam pemikiran Muslim (taghyīb al-Qur'ān), kemudian lenyapnya rasionalitas dalam nalar Muslim (taghyīb al-'aqI), dan terakhir, penghakiman terhadap pluralitas pemikiran (al-qaḍa 'ala ta'addudiyyāt fi al-islam). ${ }^{25}$

M. Shahrur menyatakan dominasi nalar hadis dimulai secara formal pada era al-Mutawakkil (247 H.), yaitu era perubahan orientasi kebijakan politik Dinasti Abbasiyyah dalam bidang pendidikan dan kebudayaan, yang mendukung 'ilmu pengetahuan Arab', setelah sebelumnya sangat mendukung upaya eksplorasi unsur-unsur pengetahuan dan kebudayaan Persia dan Yunani. ${ }^{26}$ Hal ini menandai kemenangan kelompok Ahmad bin Hanbal (241 H.) yang

${ }^{24}$ Hafiz Zakariya dan Mohd Afandi Salleh, "From Makkah to Bukit Kamang?: The Moderate versus Radical Reforms in West Sumatra (ca. 1784-1819),"International Journal of Humanities and Social Science 1, 14 (October 2011). Didownload dari ijhssnet.com. 29-12-2014 jam 05.40.

${ }^{25}$ George Tharabisyi, Min Islām al-Qur'ān Ilā Islām al-Hadìth (Beirut: Dar alSaqi, 2010), cet ke-1, 619-625.

26 M. Shahrur, Kayfa Nafham al-Sunnah al-Nabawiyyah, dikutip dari http://www.shahrour.org/? pageid=807 
dikenal sebagai pemuka kelompok ahli hadis atas dominasi kaum Muktazilah yang dikenal dengan ahli akal. Ahmad bin Hanbal kemudian menjadi ikon bagi kaum yang 'pro' terhadap hadis (ahad).

Pada abad kedelapan, Ibnu Taimiyyah (728 H.) reformis bermazhab Hanbali, ${ }^{27}$ mengeritik kaum sufi, filosof, dan fukaha. ${ }^{28}$ Fatwa-fatwanya kontroversial karena menyerang tradisi yang berkembang luas saat itu. Karena kecerdasannya, Ibnu Taimiyyah mendapat sambutan dari sejumlah intelektual saat itu. Dia bahkan dijuluki Syaikhul Islam. Dalam melancarkan kritik, Ibnu Taimiyyah menggunakan hadis sebagai dasar argumentasi. Sekalipun menggunakan hadis, sama dengan aliran lain yang bertahan dan berkembang pada abad kedelapan, namun yang membedakannya adalah prinsip ajarannya yang menolak konsep metafora dalam penafsiran teks suci. Musuh-musuh Ibnu Taimiyyah menjulukinya seorang antropomorfis (baca: mujjassim), pendukung paham yang menyatakan Tuhan memiliki atribut dan fisik seperti manusia, ${ }^{29}$ sekalipun murid-murid Ibn Taimiyyah menolak anggapan tersebut. ${ }^{30}$

Ibnu Taimiyyah percaya bahwa kebenaran bersumber dari wahyu. Seluruh yang berasal dari manusia sama sekali tidak mendapat kepercayaan seperti wahyu. Karenanya, dia meragukan seluruh pemikiran dan tradisi yang bersumber dari kreatifitas akal budi manusia. Ibnu Taimiyyah menolak mantik, logika Yunani yang berkembang dalam keilmuan Muslim. Mantik merupakan landasan dasar berfikir filosofis. Upaya tertinggi manusia dalam menggunakan akal budinya. Ibnu Taimiyyah juga menolak tasawuf, karena dinilai bersumber dari pengalaman rohani liar dan tidak islami. Pengalaman rohani harus didasarkan kepada praktik Nabi saw. dan sahabat. Tidak boleh lebih dari itu. Penolakan ini didasarkan kepada hadis. Penolakan terhadap mantik misalnya, menuntut Ibnu Taimiyyah merumuskan ulang cara berfikir yang menurutnya lebih islami, yaitu dengan mengubah sistem silogisme. Dalam model berfikir silogis, selalu diandaikan adanya dua pernyataan pokok. Pernyataan pertama memiliki cakupan lebih luas daripada pernyataan kedua. Pernyataan pertama sering disebut muqaddimah kubrā atau premis mayor, sedangkan pernyataan kedua disebut muqaddimah șughrāatau premis minor. Ibnu Taimiyyah mencoba

${ }^{27}$ H. Laoust, “Le Reformisme d'ibn Taymiya," Islamic Studies 1, 3 (1962): 27-47, diunduh dari http://www.jstor.org/stable/20832642 pada 31/12/2014 00:02. Abu al'Abbas Taqiyyuddin Ahmad bin Abdul Halim ibn Taimiyyah, Minhāj al-Sunnah alNabawiyya (tt: tp, 1986), cet. ke-1, jilid 1.

${ }^{28}$ Ibn Taimiyyah, Minhaj al-Sunnah al-Nabawiyyah, jilid 1, 573.

${ }^{29}$ Hasan bin Ali al-Saqaf, al-Salafiyyah al-Wahhābiyyah Afkāruhā al-Asāsiyyah wa Judhüruhā al-Tärikhiyyah (Beirut: Dar al-Imam al-Rawwas, tt), 40.

${ }^{30}$ Ṣadr al-Din Ali ibn Abd al-'Izz al-Hanafi, Sharh al-Tahāwiyyah fi al-'Aqìdah al-Salafiyyah (Kairo: Dar al-Ḥadith, 2005), cet. ke-1. 
mengusulkan bahwa muqaddimah kubrā harus diambil dari hadis-hadis Nabi saw. Benar tidaknya muqaddimah șughrā adalah dilihat dari tingkat kesesuaian dengan muqaddimah kubrā. Hadis Nabi saw. yang digunakan sebagai muqaddimah kubrā harus memiliki makna yang stabil. Karenanya, Ibnu Taimiyyah menolak keragaman tafsir atas hadis. Ketika sebuah teks memiliki kemungkinan makna lain, maka pengertian yang diambil adalah pengertian tersuratnya. Hal ini untuk mendukung gagasan bahwa premis mayor harus selalu benar dan tegas. Pernyataan yang tidak tegas tidak dapat dijadikan premis mayor. Karenanya, hadis harus dimaknai secara tekstual (mengikuti pengertian zahirnya). Inilah salah satu contoh bentuk penghakiman terhadap keragaman tafsir dalam Islam (al-qaḍ̄̄, 'alā al-ta 'addudiyyāt fi al-Islām).

\section{Hadis Sebagai Manhaj al-Fikr}

Ulasan sebelumnya menggambarkan sumbangan hadis terhadap pemikiran salafisme. Juan Jose Escobar Stemmann menyatakan bahwa kalangan terpelajar kelompok salafi sangat senang mempelajari hadis. Bahkan mereka mengklaim sebagai penerus ajaran Ahli Hadis. Tujuan utamanya adalah mengembalikan masyarakat ke jalan yang sesuai dengan praktik Nabi saw. ${ }^{31}$

Sampai di sini, hadis menjadi apa yang disebut Adis Duderija worldview atau weltanschaung bagi kaum salafi. Worldview sering diartikan kecenderungan kesadaran mental suatu individu atau masyarakat yang meliputi seluruh pengetahuan dan sudut pandang individu atau masyarakat yang mencakup filsafat alam, anggapan fundamental, eksistensial, norma, tema, nilai, emosi, dan etika". ${ }^{32}$ Artinya hadis menjadi cara melihat dunia yang mengukur apakah dunia ini sudah benar dan sesuai dengan apa yang dikatakan Nabi saw.

Perkataan Nabi saw. merupakan kebenaran ilahi yang harus diimani. Di sini, menjaga stabilitas makna dengan membatasi pada pengertian-pengertian tekstualnya menjadi niscaya. Meminimalisir 'kemungkinan lain' dalam suatu proses penafsiran sangat ditekankan. Sebagai contoh adalah kitab Minhāj alSunnah al-Nabawiyyah (Jalan Sunnah Nabi). Sekalipun pada mulanya buku ini ditulis untuk menyerang ajaran-ajaran Syiah Imamiyyah, namun dalam banyak bagian buku tersebut juga diulas secara kritis hampir seluruh model pemikiran Islam abad kedelapan hijriah; Sufisme, Muktazilah, Asy'ariyyah, dan Falasifah.

\footnotetext{
${ }^{31}$ Juan Jose Escobar Stemmann, "Middle East Salafism's Influence and The Radicalization of Muslim Communities in Europe," MERIA Journal 10, 3 (September 2006). Didownload dari http://meria.idc.ac.Pada 31-12-2014 jam 12.26.

${ }^{32}$ Gary B Palmer, Toward A Theory of Cultural Linguistics (Texas: University of Texas Press, 1996), 114.
} 
Standar kebenaran untuk seluruh pemikiran hanyalah sunnah dan pernyataan sahabat yang berkualitas sahih. ${ }^{33}$

Mengutip M. Shahrur, di sinilah terjadi transendensi hadis. Hadis dicerabut dari konteks historisnya. Pencerabutan ini diikuti dengan pencerabutan 'sahabat', 'ijma sahabat', 'qaul sahabat', 'adalah sahabah' ke wilayah yang meta-historis. Ketika sudah bersifat transenden, hadis dan sahabat menjadi sesuatu yang bisa diterapkan untuk segala zaman dan tempat. Di sinilah berlaku jargon al-Islam șāliḥ li kulli zamān wa makān. Kata 'al-islam' di sini merujuk kepada George Tharabisyi berarti spesifik, yaitu Islam ala hadis (Islam al-hadith), bukan lagi Islam yang didasarkan pada al-Quran yang prinsipil dan universal. Ini bukan pula Islam yang didasarkan kepada al-'aql yang kreatif dan progresif. Islam dalam nalar salafisme adalah 'Islam Hadis'. Dalam rumusan Adis Duderija, hadis telah menjadi weltanschaung atau worldview kaum salafi.

\section{Penafsiran Tekstual Terhadap Hadis}

Penafsiran tekstual terhadap teks suci telah melahirkan perdebatan hangat di kalangan sarjana. Jakobus M. Vorster melihat tekstualisme menjadi fenomena umum dalam semua agama. Dalam analisisnya, tekstualisme melahirkan fundamentalisme agama. ${ }^{34}$ Mark Woodward dan Robert Glave melihat tekstualisme dalam tradisi penafsiran Islam, sebagai gejala yang wajar, dominan, dan bertahan cukup lama. Mark Woodward mengamati penggunaan penafsiran tekstual dalam konteks wacana politik Indonesia modern, ${ }^{35}$ sedangkan Robert Gleave mengamati penggunaannya dalam tradisi teori hukum Sunni, Syi'i, ahli bahasa, kaum tradisionalis, modernis, salafis dan pengikut Ayatullah. ${ }^{36}$ Secara lebih luas, ketiganya sepakat bahwa penafsiran tekstual merupakan tradisi penafsiran teks yang dominan dalam tradisi penafsiran teks suci Islam.

Pada era belakangan muncul gugatan terhadap metode penafsiran semacam ini. Menurut Abdullah Saeed penafsiran tekstual sudah tidak relevan,

\footnotetext{
${ }^{33}$ Ibn Taimiyyah, Minhaj al-Sunnah al-Nabawiyyah, jilid 5, 178-181 dan 182-233.

${ }^{34}$ Jakobus M. Vorster, "Perspectives on the Core Characteristics of Religious Fundamentalism Today,"Journal for the Study of Religions and Ideologies, 7, 21 (Winter 2008):44-65.

${ }^{35}$ Mark R. Woodward, "Textual Exegesis as Social Commentary: Religious, Social, and Political Meaning of Indonesian Translations of Arabic Hadith Text,"Journal of Asian Studies, 52, 3 (Aug., 1993). Didownload dari http://www.jstor.org.

${ }^{36}$ Robert Gleave, Islam and Literalism: Literal Meaning and Interpretation in Islamic Legal Theory (Edinburgh: Edinburgh University Press, 2013).
} 
kalau tidak dikatakan malah berbahaya. ${ }^{37}$ Pandangan semacam ini didukung oleh para teoritisi gerakan radikal bahwa tekstualisme berhubungan erat dengan aksi-aksi kekerasan dan terorisme global. Christopher M. Blanchard, Hayat Alvi dan Qamar Fatima menilai kelompok salafi harus bertanggung jawab atas tekstualisme yang berujung pada kekerasan global (global violence) ${ }^{38}$ Berbeda dengan keduanya, Irfan Habib melihat tekstualisme telah melahirkan vandalisme dalam ilmu pengetahuan. Pemahaman tekstual terhadap teks suci berkaitan erat dengan penolakan ilmu pengetahuan modern. ${ }^{39}$ Sedangkan Sherman A. Jackson melihat bahwa arus gerakan tekstualis telah memantik lahirnya cara pandang baru yang menggunakan teori maqāsid al-sharī'ah sebagai mekanisme penafsiran teks-teks suci. ${ }^{40}$ Adis Duderija menemukan bahwa dominasi tekstualisme melahirkan kelompok baru yang disebutnya Progressive Muslim (PM). Kelompok ini mengembangkan penafsiran kritis berbasis nilai-nilai hak asasi, keadilan gender, dan hermeneutika kontekstual untuk mendapatkan penafsiran yang sesuai dengan kondisi zaman. Hal ini merupakan respon terhadap kaum Neo-Traditionalis Salafis (NTS), pengembang utama dan massif terhadap penafsiran tekstual di dunia global. PM diwakili oleh tokoh-tokoh seperti Khaled Abou al-Fadhl, Amina Wadud, Fazlur Rahman, Nurcholish Madjid dan lainnya. ${ }^{41}$

Hampir senada dengan Duderija, Jasser Auda melihat tekstualisme memicu penggunaan paradigma postmodernis oleh sementara sarjana Muslim seperti yang dilakukan oleh Mohamed Arkoun, Nasr Hamid Abu Zaid, Hassan

${ }^{37}$ Abdullah Saeed, Interpreting The Quran Towards a Contemporary Approach (New York: Routledge, 2006), 61, dan Saeed, "Some Reflections on the Contextualist Approach to Ethico-Legal Texts of the Quran," Bulletin of SOAS, 71, 2 (2008): 221-237.

${ }^{38}$ Christopher M. Blanchard, "The Islamic Traditions of Wahhabism and Salafiyya."Didownload dari fas.org/sgp/crs/misc/RS21695.pdf. 13.09.2014/13.59, Qamar Fatima, "The Rise and Fall of Taliban Regime (1994-2001) In Afghanistan: The Internal Dynamics," International Organization of Scientific Research (IOSR) Journals 19, Issue 1, Ver. I (Jan. 2014): 35-46, didownload dari www.iosrjournals.org/iosrjhss/papers/Vol19-issue1/Version-1/F019113546.pdf. 13-09-2014. 13.47. Hayat Alvi, "The diffusion of intra-islamic violence and terrorism: The impact of the proliferation of salafi/wahhabi ideologies." Diakses dari www.gloriacenter.org/wpcontent/uploads/2014/07/v18n02a05_alvi_-PDF.pdf.13.09.2014/14.33.

${ }^{39}$ S. Irfan Habib, "Modern Science and Islamic Essentialism,"Economic and Political Weekly, 43, 36 (Sep. 6 - 12, 2008): 55-61. Didownload dari http://www.jstor.org/stable/40277927. Pada 09/09/2014 04:55.

${ }^{40}$ Sherman A. Jackson, "Literalism, Empiricism, and Induction: Apprehending and Concretizing Islamic Law's Maqâsid Al-Sharî'ah in the Modern World,” Michigan State Law Review ( 2006):1469.

${ }^{41}$ Adis Duderija, "Neo-Traditional Salafi Qur'an-Sunna Hermeneutic and Its Interpretational Implications," Religion Compass 5/7 (2011): 314-325. 
Hanafi dan lainnya. Perbedaannya dengan Duderija, Auda menunjukkan sejumlah kritiknya terhadap pendekatan postmodernis ini yang menurutnya cenderung ambivalen. Di satu sisi mereka menekankan kritik terhadap ideologi dominan, namun di sisi lain mereka berpihak kepada ideologi lain. Kritik itu dia bangun di atas paradigma filsafat sistem yang dipadukan dengan konsep maq̄asid al-shari ${ }^{-} a h^{42}$ Dengan demikian, pada dasarnya, Jasser Auda sendiri tidak setuju pada paradigma tekstualisme dengan menawarkan maqāsid alshari ‘ah sistemiknya.

Dalam perspektif feminis, tekstualisme telah melahirkan paradigma misogini. ${ }^{43}$ Khaled Abou al-Fadl menyebut tekstualisme melahirkan otoriterianisme dalam proses penafsiran teks agama. ${ }^{44}$ Amin Abdullah, melihat tekstualisme melahirkan normativitas yang dalam tradisi akademik menjadi paradigma dominan dalam penelitian keagamaan. Dominasi ini melahirkan gerakan-gerakan alternatif seperti penggunaan paradigma historis secara massif di perguruan tinggi Islam di Indonesia. ${ }^{45}$ Arus historis ini menguat dengan berkembangnya diskursus hermeneutika dalam tulisan-tulisan para sarjana Muslim belakangan. Proyek yang diusung adalah mengkontekstualisasikan doktrin-doktrin agama sesuai konteksnya di masa lalu dan konteksnya di masa sekarang. Pasca hermeneutika, paradigma tekstual-kontekstual menjadi semakin marak. Bersamaan dengan itu, paradigma tekstual cenderung ditinggalkan dan diwaspadai dalam perkembangan mutakhir.

Arus penolakan semakin kuat dalam lembaga-lembaga akademik Muslim. Sekalipun, di sisi lain, paradigma tekstual masih bertahan cukup kuat dalam praktik penafsiran teks Muslim, bukan hanya di Indonesia, namun juga negara-negara minoritas Muslim seperti negara-negara Amerika Utara. Di Indonesia, Syuhudi Ismail dan Ali Mustafa Yaqub, dua sarjana hadis modern menyebut secara tegas bahwa pendekatan teksual merupakan pendekatan yang dapat digunakan dalam memahami hadis-hadis Nabi saw. ${ }^{46}$ Khaled Abou al-Fadl dan Adis Duderija melaporkan bahwa paradigma tekstual merupakan fenomena

\footnotetext{
${ }^{42}$ Jasser Auda, Maqāsid al-Shari ‘ah Ka Falsafah Li al-Tashrī‘ al-Islāmī Ru'yah Manzümiyyah (Virginia: IIIT, 2012), cet. Ke-1, 289-307.

${ }^{43}$ Lihat Fatima Mernissi, Women and Islam, an History and Theological Inqury (Oxford: Blacwell Publishers, 1991), cet. ke-5, 49-62. ke-1, 56-57.

${ }^{44}$ Khaled Abou El Fadl, Melawan “Tentara Tuhan”(Jakarta: Serambi, 2003), cet.

${ }^{45}$ A. Halil Thahir, "Dari Nalar Literalis-Normatif Menuju Nalar KontekstualisHistoris dalam Studi Islam," ISLAMICA, 5, 1 (September 2010).

${ }^{46}$ Syuhudi Ismail, Hadis Nabi Yang Tekstual dan Yang Kontekstual, Ali Mustafa Yaqub, al-Turuq al-Sahịhah fi Fahm al-Sunnah al-Nabawiyyah (Jakarta: Maktabah Darus-Sunnah, 2014), cet. ke-1, 11.
} 
yang menggejala kuat di negara-negara minoritas Muslim. Mendukung tesis HR. Gibb, keduanya menyatakan bahwa menguatnya paradigma ini di negaranegara Barat adalah karena cara pandang semacam itu menyuguhkan jawaban praktis untuk menghadapi budaya 'sekuler' yang kompleks.

Di sinilah terjadi tarik ulur antara kebutuhan terhadap teks suci dengan penafsiran terhadapnya. Antara penafsiran yang dinilai 'benar' dan penafsiran yang dinilai 'tepat' dan 'relevan'.

Di sisi lain, sebagian sarjana menuding bahwa berkembangnya paradigma tekstual tidak dapat dilepaskan dari peran al-Shāfi'i (204 H.) yang kemudian diradikalisasi sebagian ahli hadis. Nasr Hamid Abu Zayd menyatakan bahwa usul fiqh yang digagasa al-Shäfi $\bar{i}$ bertanggungjawab atas dominannya tekstualisme dalam cara berfikir umat Islam sekarang. ${ }^{47} \mathrm{M}$. Abed al-Jabiri melihat akar yang sama bahwa al-Shäfi ${ }^{\circ} \bar{i}$ merupakan pendiri epistemologi Bayāni yang merupakan epistemologi dominan dalam penafsiran teks keagamaan saat ini. ${ }^{48}$ George Tharabisyi misalnya, dalam buku Min Isläm alQur'ān ilā Islām al-Hadith berkesimpulan bahwa dominasi nalar hadis sejak abad kedua hijriah berakibat pada absennya tiga kekuatan Islam; rasionalitas (ghiyāb al- 'aqlāniyyah), kreatifitas (ghiyāb al-ibdā') dan kebebasan (ghiyāb alhurriyah). Pada tahap lebih ekstrim, M. Shahrour dan Edip Yuksel menolak otoritas hadis dalam agama. ${ }^{49}$ Khaled Abou El-Fadl hanya menolak penafsiran otoriter ala kaum Wahhabi-Salafi dan tetap menerima hadis sebagai otoritas keagamaan Islam dengan mengedepankan penafsiran yang 'canggih'. Tepatnya, penggunaan tradisi ahli hukum Islam, utamanya teori-teori ussūl al-fiqh secara maksimal. $^{50}$

Berbeda dengan Abou El-Fadl, sebagian sarjana melihat bahwa ựūl alfiqh saja belum cukup untuk mengatasi dampak buruk pemahaman tekstual terhadap hadis Nabi saw. Al-Qaraḍāwi mengemukakan pentingnya pemilahan antara konteks hadis yang berfungsi sebagai tujuan pokok (al-hadaf al-thäbit) dan instrumen pengantara yang dinamis (al-wasilah al-mutaghayyirah). ${ }^{51}$ Muhammad al-Ghazali menekankan pentingnya paradigma fiqh, di samping

${ }^{47}$ Nasr Hamid Abu Zayd, al-Imam al-Shāfi $i ̄$ wa Ta'sis al-Idiyulujiyyah alWasatiyyah (Maghrib: Markaz al-Thaqāfi al-'Arabī, 2007), cet. ke-1.

${ }^{48} \mathrm{M}$. Abed al-Jabiri, Bunyat al-'Aql al-'Arabi Dirāsah Taḥliliyyah Naqdiyyah Li Nażm al-Ma'rifah fi al-Thaqāfah al-'Arabiyyah (Beirut: Markaz Dirasat al-Wahdah al'Arabiyyah, 2009), cet. ke-9, 13.

${ }^{49} \mathrm{M}$. Shahrur, Kayfa Nafham al-Sunnah alNabawiyyah,http://www.shahrour.org/?page_id=807

${ }^{50}$ Khaled M. Abou El Fadl, Melawan "Tentara Tuhan", 56-57.

${ }^{51}$ Yusuf al-Qaradawī, Kayfa Nata‘āmal Ma'a al-Sunnah al-Nabawiyyah Ma ālim wa Ḍāābit (Virginia: IIIT, 1992), cet. Ke-5. 
profesionaliasi dengan melakukan pembagian wilayah kerja secara tegas antara ahli fiqh dan ahli hadis. Memahami hadis, menurutnya merupakan wilayah kerja ahli fiqh. Ahli hadis tidak layak mengambil peranan ini karena mereka bukan ahlinya. Dunia menuntut profesionalisasi. ${ }^{52}$ Thaha Jabir Ulwani menyatakan bahaya dan dampak buruk pemahaman tekstual (al-fahm al-Mu'jami) terhadap sunnah yang akan berimbas pada keluruhan sunnah itu sendiri. Citra sunnah menjadi rusak karena pola-pola pemahaman semacam itu. Ini tidak tepat karena, menurutnya, sunnah merupakan sumber peradaban dan pengetahuan dalam Islam selama dipahami melalui metodologi yang tepat. Karenanya, penafsiran terhadap sunnah membutuhkan penanganan khusus (kaifiyat al-ta'āmul ma'a alsunnah al-nabawiyyah). ${ }^{53}$

Para pemikir di atas sepakat bahwa tekstualisme merupakan cara pandangan dominan dalam metode penafsiran kaum ahli hadis. Di sinilah muncul hipotesis yang cukup kuat bahwa tekstualisme dan ahli hadis memiliki hubungan yang sangat dekat. Keduanya seperti dua sisi koin yang tak terpisahkan. Tekstualisme di sini berarti mengedepankan makna kamus (alma'na al-mu'jamī), meminjam bahasa Thaha Jabir, dan mengabaikan makna kontekstual. Dapat dirumuskan bahwa upaya kontekstualisasi mengambil jalan yang beragam; mulai dari menggunakan paradigma fiqh, ushul fiqh, maqasid alshari'ah, hermeneutika, dan kritik sastra.

Seperti diungkap sebelumnya bahwa tekstualisme kontemporer banyak diwakili oleh kelompok salafi. Kelompok salafi sendiri mengklaim diri sebagai reinkarnasi ahli hadis di masa lalu. Hal ini dapat dibuktikan dengan sejumlah kenyataan seperti penggunaan hadis dan ulum al-hadis sebagai mekanisme kritik dalam menghadapi tradisi Islam yang dikembangkan sufisme, fiqh mazhab, kalam skolastik, pemikiran filsafat dan tradisi sinkretik masyarakat lokal: Bahwa semua yang tidak mendapatkan justifikasi hadis merupakan praktik bidah dalam agama. Salafisme kemudian menjadi gerakan global yang mewarnai dunia Islam dengan paham pemurniannya (ideology of puritanism).

Hubungan 'erat' antara tekstualisme ahli hadis, yang melahirkan ideologi salafisme dan intoleransi dalam segala bentuknya akhir-akhir ini melahirkan citra yang buruk masyarakat Muslim dan global terhadap Islam dan kelompok ahli hadis secara khusus. Ahli hadis dipandang sebagai kelompok rigid di antara kelompok-kelompok intelektual Islam. Bahkan, ahli sumber kekacauan global

\footnotetext{
${ }^{52}$ Muhammad al-GhazāTi, al-Sunnah al-Nabawiyyah Bayna Ahl al-Hadith wa Ahl al-Fiqh (Kairo: Dar al-Shuruq, tt), 19.

${ }^{53}$ Lihat pengantar Thaha Jabir pada buku Yusuf al-Qaradawi, Kayfa Nata‘āmal Ma'a al-Sunnah al-Nabawiyyah Ma'ālim wa Dawābiṭ (Virginia: IIIT, 1992), cet. Ke-5.
} 
pada era belakangan. Di sini, muncul hipotesis bahwa tekstualisme cenderung melahirkan sikap intoleransi.

\section{Hadis dan (Kepentingan) Politik}

Hadis yang diposisikan sebagai worldview berarti telah dijadikan asumsi dasar, pandangan fundamental, kecenderungan mental dan paradigma teoritik dalam melihat segala sesuatu: pemikiran, perilaku, alam, Tuhan dan lain sebagainya. Dengan demikian, hadis juga menjadi cara pandang terhadap politik dalam arti umum, praktik berkekuasaan.

Di sini hadis terkadang diposisikan sebagai pembenaran terhadap aksiaksi politik. Dalam kasus yang ekstrim, aktor-aktor politik memalsukan hadis Nabi saw. membuat hadis yang sesuai dengan kepentingan kekuasaan mereka. ${ }^{54}$ Penggunaan hadis palsu dalam politik menunjukkan supremasi hadis dalam nalar pengguna dan masyarakatnya. Bahkan dalam sejarah Islam, diskursus politik sangat diwarnai oleh jargon-jargon yang bersumber dari hadis. Misalnya terma khiläfah, Quraish, nubuwwah, imārah, țā'ah, qạ̣ā, iḥtisāb, rishwah, dan bar ${ }^{\mathrm{r}}{ }^{55} \mathrm{Hal}$ ini membuat Ibnu Khaldun berkesimpulan bahwa bangsa Arab tak akan sanggup mendirikan negara tanpa baju agama (al- 'arab la yaḥ̦ul lahum almulk illa bi șibghah diniyyah min nubuwwah au wilayah au athar 'azīm min aldin 'ala al-jumlah). ${ }^{56}$ Terlepas apakah mereka berideologi Syiah, Ahlus-Sunnah, Muktazilah maupun Khawarij; seluruh kelompok ideologi-politik klasik ini membuktikan ketidak-sanggupan mereka berpolitik tanpa agama. Kecenderungan ini sepertinya belum menemukan titik akhirnya di belahan dunia Arab kontemporer. Perang saudara antara rezim Bashar Asad-Alawi dengan oposisi Ahlu-Sunnah Salafi, Rezim Irak dan Suriah melawan Islamic State in Iraq and Syiria (ISIS), maupun pemerintahan Iran yang demokratikwilayatul faqih di timur dan kerajaan Maroko yang merupakan keturunan Ahli Bait. Warna agama tidak akan pernah dapat dipisahkan.

Di sini, otoritas agama juga menjadi otoritas politik. Salah satu otoritas agama adalah sumber-sumber agama itu sendiri, dan tentu saja Hadis-hadis Nabi saw. memiliki ruang yang cukup luas bermain dalam percaturan wacana politik Arab.

${ }^{54}$ Muhammad 'Ajjaj al-Khathib, Ușūl al-Hadith 'Ulümuhu wa Muṣtalaḥuhu (Beirut: Dar al-Fikr, 1975), cet. ke-3, 415.

${ }^{55}$ Koleksi hadis-hadis politik dalam hampir tiga ratus halaman. Lihat Muttaqi alHind, Kanz al-'Ummal fi Sunan al-Aqwāl wa al-Af'àl (Beirut: Muassasah al-Risalah, 1985), cet. ke-5, jilid 5, 584-855.

${ }^{56}$ Ibn Khaldun, Muqaddimah Ibn Khaldun (Beirut: Dar al-Kutub al-'Ilmiyah, 2003), cet. ke-8, 119. 
Fazlur Rahman pada tahun 70-an menyatakan bahwa sejak abad kedua hijriah, hadis telah memerankan wacana politik umat Islam. Salah satunya, hadis tentang jamaah yang selamat yang muncul secara evolutif dan semakin ke belakang menjadi lebih sempurna redaksinya. Sekalipun hadis sebagai verbalisasi tradisi yang original dari era Nabi saw. Muncul pada abad kedua atas peran para sarjana fikih, namun esensinya otentik dari Nabi saw. ${ }^{57}$

\section{Penutup}

Ulasan di atas menunjukkan bahwa hadis sudah menjadi 'ideologi' bagi kaum salafi global. Ideologisasi hadis ini telah berlangsung sejak abad kedua hijriah dan mencapai kematangannya pada abad kedelapan hijriah melalui kecerdasan Syaikhul Islam Ibnu Taimiyyah. Pada abad kedelapan belas, ideologi ini dihidupkan oleh gerakan salafisme modern yang dimotori oleh Muhammad bin Abdul Wahhab. Gerakan ini melahirkan ideologi Wahhabi. Pada abad kesembilan belas, disertai revivalisme Islam, salafisme hadir melalui pemikiran Muhammad Abduh dan Rasyid Ridha. Dari ketiga ideolog inilah gerakan salafisme menyebar ke seluruh penjuru dunia. Salafisme saat ini menjadi gerakan Islam (islamic movement) yang paling agresif pada tingkat global. Segala sesuatu yang berubah demikian cepat seringkali menciptakan kekhawatiran-kekhawatiran tertentu. Inilah kondisi yang meliputi kemunculan salafisme global saat ini. Salafisme telah menempatkan hadis sebagai ideologi kontra globalisme. Wallahu A'lam.

\section{Daftar Pustaka}

Abed al-Jabiri, M. Bunyat al-'Aql al-'Arabi Dirāsah Tahliliyyah Naqdiyyah Li Nazm al-Ma'rifah fí al-Thaqāfah al-'Arabiyyah. Beirut: Markaz Dirasat al-Wahdah al-'Arabiyyah, 2009.

Abou El Fadl, Khaled M. Melawan “Tentara Tuhan.”Jakarta: Serambi, 2003.

Abu Zayd, Nasr Hamid. Al-Imam al-Shāfi ${ }_{i}$ wa Ta'sis al-Idiyulujiyyah alWasatiyyah. Maghrib: Markaz al-Thaqāfi al-'Arabī, 2007.

Ahmad, Mumtaz. Ahl-e-Hadith Movement in Bangladesh: History, Religion, Politics and Militancy.

${ }^{57}$ Fazlur Rahman, Membuka Pintu Ijtihad (Bandung: Penerbit Pustaka, 1983), cet. ke-1, 78-79, 109. 
Allen, Charles. "The Hidden Roots of Wahhabism in British India," World Policy Journal 2, 22 (2005): 87-93. Diakses dari www.jstor.org/stable/402099677 pada 19-10-2014 jam 06.57 .

Alvi, Hayat. "The diffusion of intra-islamic violence and terrorism: The impact of the proliferation of salafi/wahhabi ideologies." Diakses dari www.gloria-center.org/wpcontent/uploads/2014/07/

18n02a05_alvi_PDF.pdf.13.09.2014/14.33.

Armanios, Febe. "The Islamic Traditions of Wahhabism and Salafiyya." CRS Report for Congress. Didownload dari fas.org/sgp/crs/misc/RS21695.pdf.

Auda, Jasser. Maqāsid al-Sharī ah Ka Falsafah Li al-Tashrī‘ al-Islämì Ru’yah Manzümiyyah. Virginia: IIIT, 2012.

Blanchard, Christopher M. "The Islamic Traditions of Wahhabism and Salafiyya." Didownload dari fas.org/sgp/crs/misc/RS21695.pdf. 13.09.2014/13.59.

Blanchard, Christopher M. "The Islamic Traditions of Wahhabism and Salafiyya." CRS Report for Congress.

Burke, Jason. “Al-Qaeda.” Sumber: http:/www.jstor.org/stable/ 4147572. Diakses pada 28-08-2014 03:00.

al-Buthi, Said Ramadhan. Al-Salafiyyah Marhalah Zamāniyyah Mubārakah La Madhab Islāmī. Damaskus: Dar al-Fikr, 1988.

Chaliand, Gérard dan Arnaud Blin. The History of Terrorism From Antiquity To Al Qaeda. California: University of California Press, 2007.

Duderija, Adis. "Islamic Groups and Their World-Views and Identities: NeoTraditional Salafis and Progressive Muslims." Arab Law Quarterly 21, 4 (2007): 341-363, diakses dari http://www.jstor.org/stable/27650599 pada 28-08-2014 05:26

Duderija, Adis. "Islamic Groups and Their World-Views and Identities: NeoTraditional Salafis and Progressive Muslims." Arab Law Quarterly 21, 4 (2007): 341-363, diakses dari http://www.jstor.org/stable/27650599 pada 28-08-2014 05:26.

-------, “Neo-Traditional Salafi Qur'an-Sunna Hermeneutic And Its Interpretational Implications." Religion Compass 5/7 (2011): 314-325.

--------, “Toward a Methodology of Understanding the Nature and Scope of the Concept of Sunnah." Arab Law Quarterly 21 (2007) 1-12,sumber: www.brill.nl/alq.

Encyclopædia Britannica, Al-Qaeda, http://www.britannica.com/EBchecked/topic/734613/al-Qaeda. Diakses pada 27-12-2014, jam 10.07. 
Fatima, Qamar. "The Rise and Fall of Taliban Regime (1994-2001) In Afghanistan: The Internal Dynamics.” IOSR Journals19, Issue 1, Ver. I (Jan. 2014): 35-46, didownload dari www.iosrjournals.org/iosrjhss/papers/Vol19-issue1/Version-1/F019113546.pdf. 13-09-2014. 13.47. al-GhazāTi, Muhammad. Al-Sunnah al-Nabawiyyah Bayna Ahl al-Hadith wa Ahl al-Fiqh. Kairo: Dar al-Shuruq, tt.

Gleave, Robert. Islam and Literalism: Literal Meaning and Interpretation in Islamic Legal Theory. Edinburgh, Edinburgh University Press, 2013.

Global Status Report on Violence Prevention. Diakses dari http://www.who.int/violence_injury___ prevention/violence/status_report/en. 28-08-2014.21.906.

Habib, S. Irfan. "Modern Science and Islamic Essentialism." Economic and Political Weekly 43, 36 (Sep. 6 - 12, 2008): 55-61. Didownload dari http://www.jstor.org/stable/40277927. Pada 09/09/2014 04:55.

al-Hind, Muttaqi.Kanz al-'Ummāl fi Sunan al-Aqwāl wa al-Af'āl. Beirut: Muassasah al-Risalah, 1985.

History of Taliban. http://www-pub.naz.edu/aamghar6/History\%20of \%20the\%20Taliban. htm. Diakses pada 27-12-2014. 10.03 WIB.

Ibn Abd al-'Izz al-Hanafi, Shadr al-Din Ali. Sharh al-Tahāwiyyah fi al-'Aqìdah al-Salafiyyah. Kairo: Dar al-Hadis, 2005.

Ibn Khaldun, Abd al-Rahman. Muqaddimah Ibn Khaldūn. Beirut: Dar al-Kutub al-'Ilmiyah, 2003.

Ibn Taimiyyah. Minhāj al-Sunnah al-Nabawiyya.tt: tp, 1986.

Ismail, Syuhudi. Hadis Nabi Yang Tekstual dan Yang Kontekstual.

Jabir, Thaha. "Muqaddimah." In Yusuf al-Qaradawī. Kayfa Nata'āmal Ma'a alSunnah al-Nabawiyyah Ma'ālim wa Dawābit. Virginia: IIIT, 1992.

Jackson, Sherman A. "Literalism, Empiricism, And Induction: Apprehending And Concretizing Islamic Law's Maqâsid Al-Sharî'ah In The Modern World." Michigan State Law Review (2006):1469.

al-Khathib, Muhammad 'Ajjaj. Ușūl al-Hadith 'Ulümuhu wa Muștalahuhu. Beirut: Dar al-Fikr, 1975.

Laoust, H. “Le Reformisme d'ibn Taymiya.”Islamic Studies 1, 3 (1962): 27-47. Diunduh dari http://www.jstor.org/stable/20832642 pada 31/12/2014 00:02.

Limaye, Satu P. et.all. Religious Radicalism and Security in South Asia. Honolulu: Asia-Pasific Center for Security Studies, 2004.

Mernissi, Fatimah. Women and Islam, an History and Theological Inqury. Oxford: Blacwell Publishers, 1991. 
Muzammil, Iffah. “Global Salafisme Antara Gerakan Dan Kekerasan.” Teosofi: Jurnal Tasawuf dan Pemikiran Islam 3, 1 (Juni 2013).

Muzammil, Iffah. "Global Salafisme Antara Gerakan Dan Kekerasan.” Teosofi: Jurnal Tasawuf dan Pemikiran Islam 3, 1 (Juni 2013).

Onuoha, Freedom C. "Boko Haram: Nigeria's Extremist Islamic Sect." Al Jazeera Center for Studies. studies.aljazeera.net. diakses pada 27-122014 jam 10.18 .

Palmer, Gary B. Toward A Theory of Cultural Linguistics. Texas: University of Texas Press, 1996.

Qadhi, Yasir. "On Salafi Islam." didownload dari muslimmatters.org/2014/04/22/on-salafi-islam-dr-yasir-qadhi. Pada 2712-2014 jam 11.37.

al-Qaraḍawi, Yusuf. Kayfa Nata ‘āmal Ma'a al-Sunnah al-Nabawiyyah Ma'ālim wa Dawābit. Virginia: IIIT, 1992.

Rahman, Fazlur. Membuka Pintu Ijtihad. Bandung: Penerbit Pustaka, 1983.

al-Razi, Ahmad bin Faris bin Zakaria. Mu'jam Maqàyis al-Lughah. Beirut: Dar al-Fikr, 1979.

Saeed, Abdullah. "Some Reflections on the Contextualist Approach to EthicoLegal Texts of The Quran," Bulletin of SOAS 71, 2 (2008), 221-237.

--------, Interpreting The Quran Towards a Contemporary Approach. New York: Routledge, 2006.

al-Saqaf, Hasan bin Ali. al-Salafiyyah al-Wahhābiyyah Afkāruhā al-Asāsiyyah wa Judhüruhā al-Tärikhiyyah. Beirut: Dar al-Imam al-Rawwas, tt.

Shahrur, M. Kayfa Nafham al-Sunnah al-Nabawiyyah. Dikutip dari http://www.shahrour.org/? pageid=807

Sikand, Yoginder. "Changing Course of Kashmiri Struggle: From National Liberation to Islamist Jihad?" Sumber: http://www.jstor.org/stable/4410197. Diakses pada 27-08-2014, 02:32.

Speckhard, Anne dan Khapta Akhmedova. "The New Chechen Jihad: Militant Wahhabism as a Radical Movement and a Source of Suicide Terrorism in Post-War Chechen Society."Democracy and Security, 2 (2006): 103155.

Stemmann, Juan Jose Escobar. "Middle East Salafism's Influence and The Radicalization of Muslim Communities in Europe." MERIA Journal 10, 3 (September 2006). Didownload dari http://meria.idc.ac. Pada 31-122014 jam 12.26 .

Thahir, A. Halil. "Dari Nalar Literalis-Normatif Menuju Nalar KontekstualisHistoris dalam Studi Islam.”Islamica 5, 1 (September 2010). 
Tharabisyi, George. Min Islām Al-Qur'ān Ilà Islām Al-Hadìth. Beirut: Dar alSaqi, 2010.

Vorster, Jakobus M. "Perspectives on the Core Characteristics of Religious Fundamentalism Today." Journal for the Study of Religions and Ideologies 7, 21 (Winter 2008): 44-65.

Woodward, Mark R. "Textual Exegesis as Social Commentary: Religious, Social, and Political Meaning of Indonesian Translations of Arabic Hadith Text." Journal of Asian Studies 52, 3 (Aug., 1993). Didownload dari http://www.jstor.org.

Yaqub, Ali Mustafa. Al-Ṭuruq al-Sahịhah fi Fahm al-Sunnah al-Nabawiyyah. Jakarta: Maktabah Darus-Sunnah, 2014.

Zakariya, Hafiz dan Mohd Afandi Salleh. "From Makkah to Bukit Kamang?: The Moderate versus Radical Reforms in West Sumatra (ca. 17841819)." International Journal of Humanities and Social Science 1, 14 (October 2011). Didownload dari ijhssnet.com. 29-12-2014 jam 05.40.

Zalman, Amy. The History of Terrorism. Dikutip dalam laman http://terrorism.about.com/od/whatisterroris1/p/Terrorism.htm. Pada 03.09.2014. jam. 14.46.

Zelin, Aaron Y. "The War between ISIS and al-Qaeda for Supremacy of the Global Jihadist Movement." diunduh dari http://www.washingtoninstitute.org/policy-analysis/view/the-war-between-isis-and-al-qaedafor-supremacy-of-the-global-jihadist. Pada 27-12-2014 jam 10.12. 